\title{
GAMBARAN PEMBERIAN TERAPI MUSIK KLASIK UNTUK MENGATASI NYERI PADA PASIEN POST OPERASI HERNIA DI RSUD BARNJARNEGARA
}

\author{
Rivana Dian Imanda ${ }^{1}$ \\ Politeknik Yakpermas Banyumas, D-III Keperawatan \\ Email : jurnalyakpermas@gmail.com \\ Eko Julianto ${ }^{2}$ \\ Politeknik Yakpermas Banyumas, D-III Keperawatan \\ Email : jurnalyakpermas@gmail.com \\ Eko Sari Ajiningtyas ${ }^{3}$ \\ Politeknik Yakpermas Banyumas, D-III Keperawatan \\ Email : jurnalyakpermas@gmail.com
}

\begin{abstract}
ABSTRAK
Latar belakang : Pasien post operasi hernia yang mengalami nyeri yang tidak mendapatkan penanganan yang tepat dapat menyebabkan perasaan tidak nyaman dan tidak bisa melakukan aktivitas seperti biasanya. Terapi musik memberikan kesempatan bagi tubuh dan pikiran untuk relaksasi yang sempurna,seluruh sel dalam tubuh akan mengalami penyembuhan alami dan produksi hormon tubuh diseimbangkan dan pikiran mengalami penyegaran.Tujuan : Untuk menggambarkan asuhan keperawatan dengan terapi musik klasik untuk menurunkan nyeri pada pasien post operasi hernia.Hasil : Selama 3 hari, telah dilakukan asuhan keperawatan dengan melakukan terapi musik klasik pada pasien post operasi hernia, nyeri yang dirasakan pasien menurun. Untuk skala nyeti rata rata 1-3 nyeri ringan, 4-6 nyeri sedang, 7-10 nyeri akut.Kesimpulan : Terapi musik klasik dapat mengatasi nyeri pada pasien post operasi hernia. Teknik terapi musik klasik dapat menjadi alternatif untuk menurunkan nyeri pada pasien post operasi hernia
\end{abstract}

Kata kunci : music klasik; nyeri, post operasi hernia

ABSTRACT

Background of study : Postoperative patients with hernia that experience pain that does not get proper treatment can cause discomfort and cannot carry out activities as usual. Music therapy provides an opportunity for the body and mind to perfect relaxation, all cells in the body will experience natural healing ang the body's hprmonal production is balanced and the mind is refreshed.Objective : To describe nursing care with classical music therapy to reduce pain in postoperative hernia patients.Results : During the 3 day, nursing care was performed by classical music therapy in postoperative hernia patients, the pain felt by the patient decreased. For an average pain scale 1-3 mild pain, 4-6 moderate pain, 7-10 acute pain.Conclusion : Classical music therapy can reduce pain in postoperative hernia patients. Classical music therapy can be an alternatie to reduce pain in postoperative hernia patients.

Keywords : Clasiccal music; Pain; Post Hernia Surgery

\section{PENDAHULUAN}

Nyeri pada pasien post operasi disebabkan terjadinya kerusakan kontiunitas jaringan karena pembedahan, kerusakan kontiunitas jaringan menyebabkan pelepasan mediator kimia yang kemudian mengaktivasi nosiseptor dan memulai tranmisi nosiseptik sampai terjadi nyeri. Nyeri akan mengakibatkan mobilisasi terbatas (Economidou, 2012).

Musik diyakini memiliki kekuatan untuk mengobati penyakit dan meningkatkan kemampuan pikiran seseorang (Eka, 2011). Terapi musik memberikan kesempatan bagi tubuh 
Rivana Dian Imanda : Gambaran Pemberian Terapi Musik Klasik Untuk Mengatasi Nyeri Pada Pasien Post Operasi Hernia Di RSUD Barnjarnegara

dan pikiran untuk mengalami relaksasi yang sempurna. Kondisi relaksasi (istirahat) yang sempurna itu seluruh sel dalam tubuh akan mengalami reproduksi, penyembuhan alami akan berlangsung, produksi hormon tubuh diseimbangkan dan pikiran mengalami penyegaran (Demir, 2011).

Dari data yang tercatat diorganisasi kesehatan dunia World Health Organization (WHO) ditahun 2010, terdapat kasus hernia sebanyak 845.000 dan total jumlah tindakan herniorraphy yang dilakukan sekita 710.000 kasus. Kasus tersebut menimbulkan masalah, terutama pada sektor sosial dan perekonomian masyarakat dikarenakan untuk melakukan tindakan herniorraphy menggunakan anastesi umum maupun regional memerlukan biaya yang besar di bandingkan dengan anastesi lokal (Walter,2013).

Menurut ILO (International Labour Organization) pada tahun 2013, diperkirakan 500.000 penduduk di Amerika dan 33.000 penduduk di Belanda kehilangan produktifitas kerja setiap tahunnya karena hernia dan setiap 15 detik terdapat 160 pekerja mengalami sakit akibat kerja. Berdasarkan distribusi kasus penyakit cerna rawat inap di Indonesia pada tahun 2014 kasus hernia menempati urutan ke-8 dengan jumlah kasus sebesar 18.145 kasus, dan 273 diantaranya meninggal dunia (Sari, 2017).

Di Indonesia penyakit hernia menempati urutan ke delapan dengan jumlah 291.145 kasus. Menurut data yang diperoleh di Jawa Tengah, mayoritas penderita selama bulan Januari - Desember 2007 di perkirakan 425 penderita peningkatan angka kejadian hernia di Indonesia (Aisyah, 2015).
Menurut data statistik yang di peroleh di Rumah Sakit Umum Daerah Banyumas khususnya ruang Dahlia penyakit hernia pada tahun 2011 merupakan urutan ke-7, sedangkan pada tahun 2012 sampai menjadi urutan ke-5 dari 10 besar kasus di ruang Dahlia. Berdasarkan statistik diatas, angka kejadian hernia di Rumah Sakit Umum Daerah Banyumas, selalu masuk pada 10 besar kasus diruangan Dahlia. Hernia bila tidak di tangani dengan tepat, akan menyebabkan kematian karena distensi abdomen, shok anapilaktik sampai terjadi asidosis metabolis (Pambudi, 2013).

\section{METODE PENELITIAN}

Metode yang digunakan dalam studi kasus ini adalah metode deskriptif yaitu suatu metode studi kasus yang ditujukkan untuk menggambarkan fenomena-fenomena yang ada, yang berlangsung pada saat ini atau saat yang lampau (Husna, 2018). Studi kasus ini dilakukan dengan menggambarkan pemberian terapi musik klasik dalam pada pasien post operasi hernia yang bertujuan untuk mengetahui gambaran pengaruh musik klasik untuk menurunkan nyeri pada pasien post operasi hernia.

\section{HASIL DAN PEMBAHASAN}

Pembahasan dilakukan secara komperhensif pada Ny. S berjenis kelamin perempuan umur 72 tahun dengan post operasi hernia. Teknik musik klasik merupakan tindakan terapi nonfarmakologi untuk mengurangi skala nyeri intensitas sedang sampai ringan. Tindakan ini merupakan edukasi tentang teknik musik klasik, demontrasi cara melakukan teknik musik klasik dan observasi skala nyeri. 
Diagnosa keperawatan utama yang ditemukan pada Ny. S yaitu nyeri akut berhubungan dengan agen cedera fisik. Nyeri akut merupakan pengalaman sensori dan emosial yang tidak menyenangkan yang diakibatkan karena adanya kerusakan jaringann yang actual atau potensial atau bisa digambarkan dalam hal kerusakan sedemikian rupa.

Mekanisme timbulnya nyeri didasari oleh proses multipel yaitu nosisepsi, sensitisasi, ekstabilitas perifer, perubahan fenotip, sensitisasi sentral, eksitabilitas ektopik, reorganisasi struktural, dan penurunan inhibisi. Antara stimulus cedera jaringan dan pengalaman subjektif nyeri terdapat empat proses tersendiri : tranduksi, transmisi, modulasi, dan persepsi.

Intervensi untuk mengatasi nyeri pada Ny. S diharapkan setelah dilakukan tindakan keperawatan yaitu dengan memberikan terapi musik klasik selama 3 x 20 menit masalah nyeri dapat berkurang dengan kriteria hasil nyeri yang dilaporkan, panjangnya episode nyeri, ekspresi nyeri wajah, berdasarkan pemeriksaan kategori nyeri sedang dengan skor 4-6.

Tindakan implementasi keperawatan yang dilakukan adalah memberikan terapi musik klasik terhadap Ny. $\mathrm{S}$ telah terjadi penurunan tingkatan nyeri, dimana penulis melakukan observasi tingkat nyeri menggunakan skala VDS menunjukan penurunan dari 6 menjadi 3 dimana menjadi kategori nyeri ringan. Teori ini pertama kali di kemukakan oleh Melzack dan Wall pada tahun 1965. Teori gate control dari Melzack dan Wall (1965) menyatakan bahwa implus nyeri dapat diatur atau dihambat oleh mekanisme pertahanan di sepanjang sistem saraf pusat. Teori ini mengatakan bahwa implus nyeri dihantarkan saat sebuah pertahanan dibuka dan implus dihambat saat sebuah pertahanan ditutup. Upaya menutup pertahanan tersebut merupakan dasar teori menghilangkan yeri

Nyeri adalah pengalaman sensorik dan emosional tidak menyenangkan dengan kerusakan jaringan atau potensial atau digambarkan sebagai suatu kerusakan (International Association for the Study of Pain dalam NANDA, 2015). Ada empat tahap dalam proses terjadinya nyeri yaitu transduksi merupakan proses perubahan rangsangan nyeri menjadi suatu aktivitas listrik yang akan diterima ujung-ujung saraf. Rangsangan ini dapat berupa stimulasi fisik, kimia, ataupun panas. Transmisi adalah proses penyaluran impuls listrik yang dihasilkan oleh proses transduksi sepanjang jalur nyeri, dimana molekul-molekul dicelah sinaptik mentransmisi informasi dari satu neuron ke nouron berikutnya. Modulasi adalah proses modifikasi terhadap rangsang. Modifikasi ini dapat terjadi pada sepanjang titik dari sejak transmisi pertama sampai ke korteks serebri. Persepsi adalah proses terakhir saat stimulasi tersebut sudah mencapai korteks sehingga mencapai tingkat kesadaran, selanjutnya diterjemahkan dan diitndaklanjuti berupa tanggapan terhadap nyeri tersebut (Tamsuri, 2012).

Menurut Hidayat

(2012), munculnya nyeri berkaitan erat dengan reseptor dan adanya rangsangan. Reseptor nyeri yang dimaksud adalah nociceptor, merupakan ujung-ujung saraf sangat bebas yang memiliki sedikit atau bahkan tidak memiliki myelin yang tersebar pada kulit dan mukosa, khususnya pada visera, 
Rivana Dian Imanda : Gambaran Pemberian Terapi Musik Klasik Untuk Mengatasi Nyeri Pada Pasien Post Operasi Hernia Di RSUD Barnjarnegara

persendian, dinding arteri, hati, dan katong empedu.

Gambar 1

Skema Perjalanan Nyeri

\begin{tabular}{|c|c|}
\hline$\underset{\mathbf{i}}{\text { Stimulas }}$ & Reseptor \\
\hline $\begin{array}{l}\text { 1. Kerusaka } \\
\text { n jaringan } \\
\text { 2. Termal } \\
\text { 3. Listrik } \\
\text { 4. Mekanis }\end{array}$ & $\begin{array}{l}\text { NOCICEPTOR } \\
\text { ujung-ujung saraf } \\
\text { sangat bebas yang } \\
\text { punya sedikit myelin, } \\
\text { yang tersebar dikulit } \\
\text { dan mukosa, khususnya } \\
\text { pada visera, persendian, } \\
\text { dinding arteri, hati, dan } \\
\text { kantong empedu. }\end{array}$ \\
\hline
\end{tabular}

Menurut Wilkinson \& Ahern (2012), batasan karakteristik dari diagnosa nyeri akut ditandai dengan data subyektif mengungkapkan secara verbal atau melaporkan nyeri dengan isyarat. Sedangkan data obyektif yaitu posisi untuk menghindari nyeri, perubahan tonus otot (dengan rentang dari lemas tidak bertenaga sampai kaku), perilaku ekspresif (misalnya gelisah, merintih, menangis, kewaspadaan berlebih, peka terhadap rangsang dan menghela nafas panjang), perilaku distraksi, perilaku menjaga atau melindungi, ekspresi wajah, dan berfokus pada diri sendiri.

Nyeri berpengaruh terhadap aktivitas sehari-hari seperti tidur, nafsu makan, konsentrasi, pekerjaan, hubungan interpersonal, hubungan pernikahan, aktivitas di rumah, serta status emosional. Menurut Erda (2012), jika nyeri tidak segera diatasi maka akan menggangu istirahat, konsentrasi, dan kegiatan yang bisa dilakukan seperti mobilitas fisik.
Pasien akan merasa kurang nyaman dan tidak bisa melakukan aktivitas seperti biasanya.

Diagnosa nyeri akut sebagai diagnosa utama dikarenakan dalam menentukan prioritas masalah terdapat beberapa urutan prioritas, diantaranya yang pertama yaitu berdasarkan tingkat kegawatan yang dilatar belakangi dari prinsip pertolongan pertama yaitu dengan membagi prioritas diantaranya prioritas tinggi, prioritas sedang, dan prioritas rendah (Hidayat, 2012).

nyeri secara komprehensif, rasional : untuk mengetahui sejauh mana nyeri terjadi, mengetahui tingkat skala nyeri pasien, untuk mengetahui tindakan yang nyaman dilakukan bila nyeri muncul. Memonitor vital sign, rasional : untuk memantau kondisi pasien atau mengidentifikasi masalah dan mengevaluasi respon pasien terhadap intervensi. Ajarkan pasien penggunaan teknik non farmakologi (teknik musik klasik), rasional : teknik musik klasik mampu menurunkan nyeri pada pasien post operasi, karena relatif kecilnya peran otot-otot skeletal dalam nyeri pasca operasi.

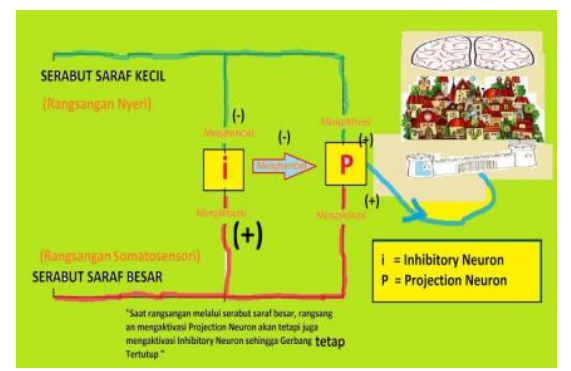

Gambar 4.2 Gate Control Theory Sumber :Melzacek \& Wall (2006) 
Tabel 2

Hasil Perubahan Tingkat Nyeri

\begin{tabular}{|c|c|c|}
\hline Hari 1 & Hari 2 & Hari3 \\
\hline $\begin{array}{l}\text { Sebelum : } \\
\text { Sebelum } \\
\text { dilakukan } \\
\text { tindakan } \\
\text { teknik } \\
\text { musik } \\
\text { klasik } \\
\text { diperoleh } \\
\text { skala nyeri } \\
6 \quad \text { dengan } \\
\text { kategori } \\
\text { nyeri } \\
\text { sedang } \\
\text { Sesudah; } \\
\text { Sesudah } \\
\text { dilakukan } \\
\text { tindakan } \\
\text { teknik } \\
\text { musik } \\
\text { klasik } \\
\text { diperoleh } \\
\text { skala nyeri } \\
5 \quad \text { dengan } \\
\text { kategori } \\
\text { nyeri } \\
\text { sedang.. }\end{array}$ & 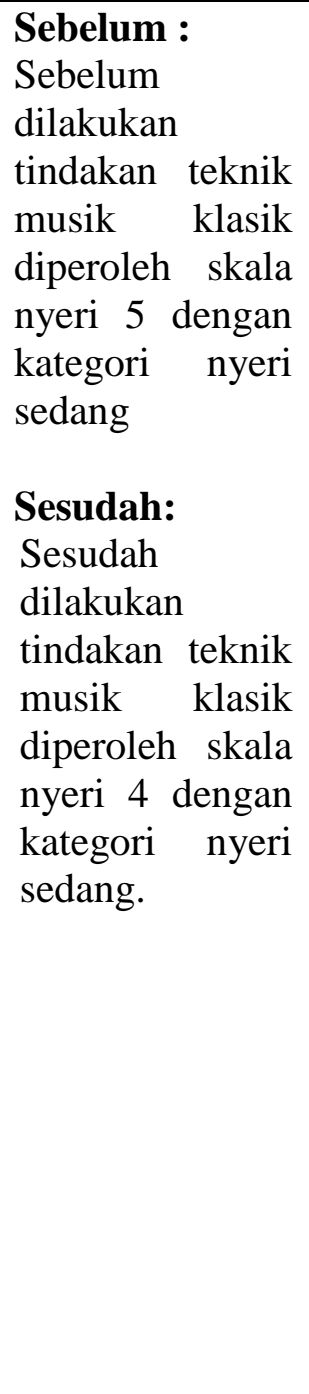 & $\begin{array}{l}\text { Sebelum } \\
\text { : } \\
\text { Sebelum } \\
\text { dilakukan } \\
\text { tindakan } \\
\text { teknik } \\
\text { musik } \\
\text { klasik } \\
\text { diperoleh } \\
\text { skala } \\
\text { nyeri } \quad 4 \\
\text { dengan } \\
\text { kategori } \\
\text { nyeri } \\
\text { sedang } \\
\text { Sesudah: } \\
\text { Sesudah } \\
\text { dilakukan } \\
\text { teknik } \\
\text { musik } \\
\text { klasik } \\
\text { diperoleh } \\
\text { skala } \\
\text { nyeri } \quad 3 \\
\text { dengan } \\
\text { kategori } \\
\text { nyeri } \\
\text { ringan. }\end{array}$ \\
\hline
\end{tabular}

Adapun evaluasi yang diperoleh dari diagnosa nyeri akut yaitu masalah tingkatan nyeri teratasi, hal ini ditunjukkan dengan keadaan umum yang lebih baik dari sebelumnya. Data subyektif pasien Ny. S mengatakan nyeri sudah berkurang dan lebih nyaman dari sebelumnya dengan hasil pengkajian nyeri meliputi: Provoking : nyeri karena post operasi hernia. Quality: nyeri dirasakan senut-senut. Region : daerah nyeri pada lipatan paha sebelah kiri. Scale : skala nyeri 3. Time : waktunya hilang timbul. Data obyektif Pengkajian vital sign meliputi : tekanan darah $135 / 90 \mathrm{mmHg}$, nadi $80 \mathrm{x} /$ menit, suhu : 36 , respiratori : 22 $\mathrm{x} /$ menit, pasien trlihat lebih nyaman. Dengan ndikator nyeri yang dilaporkan awal 3 tujuan 4 akhir 4 , panjangnya episode nyeri awal 3 tujuan 4 akhir 4 , dan ekspresi nyeri wajah awal 3 tujuan 4 akhir 4 . Sehingga tindakan lanjut dihentikan.

\section{SIMPULAN}

Setelah

dilakukan implementasi pada Ny. S umur 72 tahun selama tiga hari berturut-turut pada tanggal 23 Mei 2019 sampai 25 Mei 2019, terbukti teknik musik klasik dapat menurunkan nyeri dari skala sedang (4-6) sampai skala ringan (13). Hal ini sesuai dengan tujuan penulis yang menyatakan bahwa teknik musik klasik dapat menurunkan nyeri post operasi dari skala sedang (4-6) sampai skala ringan(1-3).

\section{SARAN}

Berdasarkan kesimpulan yang didapat dari studi kasus, penulis menyampaikan beberapa saran, antara lain :

Untuk Bangsal Kenanga Diharapkan dapat menjadi intervensi pada asuhan keperawatan dalam pemberian terapi musik klasik untuk mengatasi nyeri.

Untuk Institusi Rumah Sakit Diharapkan institusi pelayanan dapat memberikan kesempatan perawat menerapkan terapi musik pada pasien - pasien yang dirawat di RSUD $\mathrm{Hj}$. Anna Lasmanah Banjarnegara

Untuk Penulis Lain

Memberikan masukan kepada penulis lain untuk dapat mengoptimalkan 
Rivana Dian Imanda : Gambaran Pemberian Terapi Musik Klasik Untuk Mengatasi Nyeri Pada Pasien Post Operasi Hernia Di RSUD Barnjarnegara

intervensi terapi musik klasik pada pasien untuk mengatasi nyeri.

\section{UCAPAN TERIMA KASIH}

1. Puji syukur kepada Tuhan Yang Maha Esa, karena atas berkat dan rahmat-Nya, penulis dapat menyelesaikan Karya Tulis Ilmiah.

2. Ibu Rahaju Ningtyas, S.Kp.,M.Kep. selaku Direktur Politeknik Yakpermas Banyumas.

3. Ibu Ns. Dwi Astuti, M.Kep. selaku dosen penguji.

4. Bapak Eko Julianto, A.Kep.,S.Pd.,M.Kes.,CWCC selaku dosen pembimbing I dalam penyusunan karya tulis ilmiah ini.

5. Ibu Ns. Eko Sari Ajiningtyas, S.St.,M.Kes. selaku dosen pembimbing II dalam penyusunan karya tulis ilmiah ini.

6. Kedua orang tua saya, bapak Riswanto dan ibu Rusmiyati. Dimana beliau sudah berjuang dan memberikan dukungan moral ataupun moril, materil serta kasih sayang kepada penulis.

7. Adik Sabrina Agustin Krisanji dan Ghaitza Salsabila Arwa yang selalu memberikan semangat.

8. Keluarga yang selalu mendo'akan penulis menjadi orang sukses.

9. Teman-teman kelas 3C yang selalu memberi semangat dan motivasi yang baik kepada penulis dalam menyusun karya tulis ilimiah ini.

10. Teman-teman satu angkatan Politeknik Yakpermas Banyumas tahun angkatan 2017.

\section{DAFTAR PUSTAKA}

Aisyah dkk. (2015). Faktor Yang Berhubungan Dengan Kejadian Penyakit Hernia Pada Laki Laki Di Rumah Sakit Umum Dr. Soedarso Pontianak. Respository Universitas Muhamadiyah Pontianak.

Asmadi. (2008). Teknik Prosedural Keperawatan: Konsep dan Aplikasi

Arif, 2013 Gangguan Gastointestinal: Asuhan Keperawatan Medikal Bedah. Jakarta : Salemba Medika

Andra, S. W., \& Yassie, M. P. (2013). KMB 1 Keperawatan Medikal Bedah Keperawatan Dewasa Teori dan Contoh Askep. Yogyakarta: Nuha Medika.

Aditi, Rahargian. (2012). Manfaat Musik Instumental Tahun 2012

Arikunto. 2006. Prosedur Suatu Pendekatan Praktek. Jakarta : PT. Rineka Cipta.

Banoe. (2011) Kamus Musik.

Yogyakarta.

http://www.google.com/url?sa

$=\mathrm{t} \&$ source $=$ web $\& \mathrm{rct}=\mathrm{j} \&$ url $=\mathrm{ht}$ tp://journal.unj.ac.id/unj/index. php/aksis/article/download/328 2/2343\&ved $=2$ aHUKEwiq3su RtovlAhXFgl8KHexbCB8QFj AAegQIBxAB\&usg=AOvVaw 3VWWoLb1MXAqKcQc8lyUQ

Dermawan, 2012. Proses Keperawatan Penerapan Konsep dan Kerangka Kerja. Gosyeng Publising : Yogyakarta.

Demir, Yurdanur. (2011). Non farmacological therapies in pain management science. Abant izt baysal university, Bolu Health science hight school turkey. 
Economidou. E. et al., (2012). Healt science Journal. Volume 6, Issue 3 (Jully-September 2012).

Hidayat, (2011). Metode Penelitian Keperawatan dan Teknik Analisa Data. Jakarta : Salemba Medika.

Kozier, B (2010). Buku Ajar Fundamental Keperawatan : Konsep, Proses, dan Praktik. Jakarta: EGC.

Muttaqin, 2011. Buku Saku Gangguan Muskoloskeletal Aplikasi Pada Praktik Klinik Keperawatan. EGC: Jakarta.

Muttaqin, Arif \& Sari, Kumala. 2011. Gangguan Gastrointestinal: Aplikasi Asuhan Keperawatan Medika bedah. Jakarta : Salemba medika.

Musbikin, I. (2009). Kehebataan Musik Klasik. Jakarta : Power Books (IHNIDA).

Nursalam. (2011). Asuhan Keperawatan pada Pasien dengan Gangguan Sistem Perkemihan. Jakarta: Salemba Medika.

Pambudi, A. W. (2013). Asuhan Keperawatan Pada Tn. T Dengan Nyeri Akut Post Oprasi Herniorraphy Inguinalis Lateralis Dextra di Ruang Dahlia RSUD Banyumas. THESIS Available From http://Respiratory.UMP.ac.id/2 264

Prasetyo. (2010). Konsep dan Proses Keperawatan Nyeri. Yogyakarta: Graha Ilmu.

Sari, I. M. (2017). Faktor-Faktor yang Berhubungan Dengan Kejadian Hernia Inguinalis pada Pasien Dewasa Di Rsud Wonosari Tahun 2015-2016. THESIS.
Suhartini. (2011). Music and music intervention for therapic purposes in patients with ventilator support:gamelan music perpective. Nurse media journal of nurshing, 1.

Sjamsuhidayat, R \& Wim, de Jong (ed). 2004. Buku Ajar Ilmu Bedah. Jakarta: EGC

Sukmadinata, N.S. 2011 Metode Penelitian Pendidikan. Bandung: Remaja Rosadakarya Walter, T. H. (2013). Kejadian Hernia. Available from http://www.merriamwebster.com/medical/herniorra ohy.

Bulecheck, G. M., Butcher, H. H., Dochterman, J. M., \& Wagner, C. M. (2016). Nursing Interventions Classification (NIC), Eds. 6. Singapore : Elsevier.

Herdman, T. H., \& Komitsuru, S. (2015). Nanda International Diagnosa Keperawatan : Definisi \& Klasifikasi 2015-2017, Eds. 10. Jakarta : EGC.

Hidayat. (2012). Kebutuhan Dasar Manusia, Aplikasi Konsep dan Asuhan Keperawatan. Jakarta : Salemba Medika.

Tamsuri, Anas. (2012). Konsep dan Penatalaksanaan Nyeri. Jakarta : EGC. 